Jurnal IImiah Iqra'

2541-2108 [Online] 1693-5705 [Print]

Tersedia online di: http://journal.iain-manado.ac.id/index.php/JII

\title{
Peningkatan Kemampuan Menulis Teks Eksposisi Menggunakan Metode Collaborative Writing
}

\author{
Ramadhan Jamhar \\ Universitas Muhammadiyah Kupang \\ ramadhanjamhar31@gmail.com \\ Idris Mboka \\ Universitas Muhammadiyah Kupang \\ ramadhanjamhar31@gmail.com
}

\section{Sidik}

\author{
Universitas Muhammadiyah Kupang \\ ramadhanjamhar31@gmail.com
}

\begin{abstract}
Abstrak
Penelitian Tindakan Kelas ini dilakukan pada siswa kelas VII A SMP Muhammadiyah Kupang tahun ajaran 2018/2019 yang berjumlah 32 siswa. Penelitian ini bertujuan untuk mendeskripsikan peningkatan proses dan peningkatan hasil pembelajaran menulis teks eksposisi dengan menggunakan metode collaborative writing. Adapun teknik pengumpulan data yang dilakukan dengan cara wawancara, pengamatan, tes, dan dokumentasi. Teknik analisis data dilakukan dengan cara analisis deskriptif kualitatif dan kuantitatif. Data kualitatif diperoleh dari hasil wawancara, lembar pengamatan dan dokumentasi. Sedangkan data kuantitatif diperoleh dari hasil tes menulis teks eksposisi setelah menggunakan metode collaborative writing.

Hasil penelitian menunjukkan bahwa metode collaborative writing dapat meningkatkan kemampuan siswa dalam pembelajaran menulis teks eksposisi kelas VII A SMP Muhammadiyah Kupang tahun ajaran 2018/2019. Hal tersebut dapat dilihat dari hasil menulis teks eksposisi mengalami peningkatan yang signifikan pada setiap siklus. Pada siklus I, rata-rata nilai yang diperoleh siswa sebesar 66,09 dan mengalami peningkatan pada siklus II, yaitu 74, 53 .

Kata kunci: Teks Eksposisi; Collaborative Writing
\end{abstract}




\begin{abstract}
This research was done at the first grade students of SMP Muhammadiyah Kupang $2018 / 2019$ academic year involved of 32 students. The research is aimed at dercribing the improvement of process and learning outcomes after implementing the collaborative writing as the method in teaching exposition text. This study applied action research technique. The research consisted of two cycles with three meetings in each cycle. The data obtained through interview, observation checklist, test and documentation. The data then analyzed qualitatively and quantitatively.
\end{abstract}

The research showed that the collaborative writing was effective to improve the students' ablity in writing exposition text and the class situation.

Keywords: Exposition Text; Collaborative Writing

\title{
Pendahuluan
}

Belajar bahasa adalah belajar berkomunikasi. Oleh karena itu, pembelajaran bahasa diarahkan untuk meningkatkan keterampilan dalam berkomunikasi secara lisan maupun tertulis. Pembelajaran bahasa tidak terlepas dari empat keterampilan berbahasa yaitu, keterampilan menyimak, bicara, membaca, dan menulis (Jamhar \& Dkk., 2018). Selain itu, belajar merupakan upaya siswa dalam memaksimalkan ketercapaian Standar Kompetensi Lulusan (SKL). Standar Kompetensi Lulusan merupakan kemampuan kualifikasi kemampuan lulusan yang mencakup sikap, pengetahuan dan keterampilan sesuai standar nasional yang telah disepakati (Pawero, 2017).

Dalam penelitian ini penulis lebih memfokuskan pada keterampilan menulis. Menulis dapat melatih siswa mengungkapkan ide, gagasan, atau menginformasikan maksud dan tujuannya lewat bahasa tulis. Richards dan Renandya mengungkapkan aktivitas menulis merupakan suatu bentuk manifestasi kemampuan dan keterampilan berbahasa paling sulit dikuasai bahkan oleh penutur asli bahasa yang bersangkutan sekalipun. Kesulitannya tidak hanya pada kebutuhan untuk menghasilkan dan mengatur gagasan, menggunakan pilihan kosa kata, kalimat, dan organisasi paragraf yang tepat, tetapi juga mengubah gagasan semacam itu menjadi teks yang mudah dibaca (Richards \& Renandya, 2002).

Oleh karena itu, siswa harus mempunyai kemampuan atau keterampilan dalam menuangkan ide atau gagasan sehingga pembaca dapat memahami atau dapat menangkap maksud yang disampaikan oleh penulis itu sendiri. Begitu pun 
dalam menulis teks eksposisi, siswa mempunyai kemampuan untuk menyampaikan atau mengiformasikan sesuatu objek kepada pembaca. Namun kenyataannya, masih ada siswa yang mengalami kesulitan dalam menulis teks ekposisi khususnya siswa kelas VII A SMP Muhammadiyah Kupang. Siswa bosan dan kurang semangat dalam proses pembelajaran menulis teks eksposisi, banyak siswa yang bermain-main dan bahkan tertidur saat proses pembelajaran berlangsung. Hal ini disebabkan strategi pembelajaran yang digunakan dalam proses pembelajaran masih konvensional sehingga kurang membangkitkan semangat siswa dalam mengikuti proses pembelajaran.

Ketika membicarakan tujuan pendidikan maka pendidikan itu harus tersusun secara apik dan metodik (Daeng Pawero, 2018). Strategi pembelajaran mempunyai pengaruh yang besar dalam proses pendidikan. Strategi pembelajaran yang tepat dapat menciptakan situasi belajar yang efektif dan efesien. Salah satunya adalah dengan menggunakan metode Collaborative Writing. Collaborative Writing merupakan cara siswa bekerja dalam komunitas sebagai pembaca dan penulis dan menegosiasikan makna dan simbol yang digunakan dalam teks. Siswa diminta untuk bersama-sama mendiskusikan sebuah topik, merencanakan kerangka penulisan, dan memasukkan unsur teks (paragraf, kalimat, ungkapan, dan kata-kata) (Alwasilah, 2004).

Berdasarkan masalah yang dihadapi siswa kelas VII A SMP Muhammadiyah Kupang tahun ajaran 2018/2019, maka penelitian ini bertujuan untuk mendeskripsikan peningkatan proses dan peningkatan hasil dalam pembelajaran menulis teks eksposisi dengan menggunakan metode Collaborative Writing pada siswa kelas VIIA SMP Muhammadiyah Kota Kupang tahun ajaran 2018/2019.

\section{Kajian Teori}

\section{Menulis}

Menulis merupakan suatu kegiatan yang bersifat produktif dan ekspresif. Produktif dan ekspresif mengandung arti bahwa kedua karakteristik tersebut berfungsi sebagai penyampai informasi. Dikatakan produktif karena kegiatan menulis merupakan kegiatan yang bersifat menghasilkan suatu karya tulis berupa hasil ungkapan-ungkapan gagasan pikiran seseorang. Sedangkan ekspresif mengandung arti tepat (mampu) memberikan (ungkapan) gambaran, maksud, gagasan, dan perasaan (Azmussya'ni, Wangid, \& Nur, 2014). Sedangkan menurut 
Gie, menulis diistilahkan dengan mengarang yaitu segenap rangkaian kegiatan seseorang mengungkapkan gagasan dan menyampaikannya kepada masyarakat pembaca untuk dipahami (Gie, 2002).

Dalman menjelaskan bahwa menulis memiliki beberapa tujuan yaitu sebagai berikut: (1) tujuan penugasan, yaitu para pelajar, menulis sebuah karangan dengan tujuan untuk memenuhi tugas yang diberikan oleh guru atau lembaga, (2) tujuan estetis yaitu menulis dengan tujuan untuk menciptakan sebuah keindahan (estetis) dalam sebuah puisi, cerpen, maupun novel, (3) tujuan penerangan; surat kabar maupun majalah merupakan salah satu tujuan media yang berisi tulisan dengan tujuan penerangan, (4) tujuan pernyataan diri untuk membuat surat pernyataan untuk tidak melakukan pelanggaran atau surat perjanjian, (5) tujuan kreatif; menulis selalu berhubungan dengan proses kreatif, terutama dalam menulis karya sastra, baik itu bentuk puisi maupun prosa, dan (6) tujuan konsumtif, yaitu sebuah tulisan diselesaikan untuk dijual dan dikonsumsi oleh para pembaca (Dalman, 2016).

\section{Collaborative Writing}

Pembelajaran kolaboratif adalah pembelajaran yang melibatkan siswa dalam suatu kelompok untuk membangun pengetahuan dan mencapai tujuan pembelajaran bersamamelalui interaksi sosial di bawah bimbingan pendidik baik di dalam maupun diluar kelas, sehingga terjadi pembelajaran yang penuh makna dan siswa akansaling menghargai kontribusi semua anggota kelompok. Sejalan dengan itu, Shachar menyatakan bahwa dengan bekerja kelompok, siswa menikmati lebih banyak kesempatan untuk melihat teman mereka berpikir dan menciptakan gagasan baru. Dalam diskusi kelompok, siswa cenderung merasa bebas untuk mencoba gagasan baru. Selain itu, siswa memiliki banyak kesempatan untuk belajar dan mengembangkan pemahaman yang lebih besar tentang orang lain dengan beragam kebutuhan sosial, interpersonal, penyesuaian, dan pembelajaran (Shachar, 2003).

Menurut Cameron, menulis kolaboratif merupakan konsep pembelajaran Vygotsky. Menurut Vygotsky, perkembangan dan pembelajaran manusia terjadi dalam konteks sosial (Cameron, 2001). Dengan kata lain, manusia belajar sesuatu dari orang-orang di sekitar mereka. Sejalan dengan ini, penulisan kolaboratif mengacu pada situasi di mana siswa ditempatkan dalam kelompok untuk menghasilkan teks dan diharapkan bahwa mereka dapat belajar dari rekan-rekan mereka dalam kelompok. 
Pada dasarnya, collaborative writing berarti bahwa siswa bergabung dengan satu atau lebih teman sejawat untuk melalui proses penulisan (Luna \& Ortiz, 2013). Widodo menegaskan bahwa Collaborative Writing menawarkan sejumlah kelebihan. Mendorong siswa untuk bekerja sama dan mempromosikan kesempatan yang sama bagi setiap siswa untuk berpartisipasi dalam proses penulisan. Siswa berbagi gagasan dan sumber bahasa satu sama lain sepanjang proses penulisan (Widodo, 2006). Selanjutnya, Collaborative Writing dapat membangun interaksi sosial di kelas; para siswa mencoba menggabungkan gagasan yang berbeda menjadi ide yang kompak sehingga masing-masing ide mereka bisa disatukan. Ini juga melatih siswa untuk menyerasikan kegiatan menulis karena mereka berkolaborasi dalam menyelesaikan produk penulisan (yaitu sebuah paragraf atau esai). Terakhir, Collaborative Writing juga mendorong siswa untuk berpikir kritis, karena mereka meninjau dan memberi umpan balik satu sama lain.

Collaborative Writing dapat menempatkan siswa sebagai pendengar dan membantu mereka agar menerima komentar dari teman lain dan mendorong siswa untuk terlibat dalam negosiasi makna karena siswa berusaha untuk mengklarifikasi makna pesan yang diberikan dalam sebuah paragraf atau esai. Selanjutnya, memotivasi siswa untuk menulis dengan hati-hati dan membangun kepercayaan diri dalam menulis serta membantu siswa untuk mengevaluasi tulisan mereka sendiri dengan lebih baik. Bagi guru, Collaborative Writing membantu siswa menjadi kurang bergantung pada komentar guru karena tanggapan dan umpan balik siswa diprioritaskan dalam proses belajar-mengajar. Umpan balik rekan dapat meringankan beban kerja guru. Guru mengklarifikasi komentar yang dibuat oleh siswa, dan membimbing siswa untuk mengembangkan dan merevisi pekerjaan mereka lebih lanjut. Dengan kata lain, guru sebatas sebagai fasilitator dan supervisor.

\section{Metode}

Penelitian ini adalah Penelitian Tindakan Kelas (PTK). Menurut Taggart prosedur pelaksanaan PTK, mencakup: penetapan fokus permasalahan, perencanaan tindakan, pelaksanaan tindakan, pengamatan interpretasi, dan refleksi (Aqib, 2006).

Penetapan fokus masalah penelitian, meliputi kegiatan merasakan adanya masalah, analisis masalah, dan perumusan masalah. Perencanaan tindakan, meliputi kegiatan membuat skenario pembelajaran, mempersiapkan fasilitas dan sarana 
pendukung yang diperlukan kelas, mempersiapkan instrumen untuk merekam dan menganalisis data mengenai proses dan hasil tindakan, melaksanakan simulasi pelaksanaan tindakan perbaikan untuk menguji keterlaksanaan rancangan. Pelaksanaan tindakan, meliputi siapa melakukan apa, kapan, di mana dan bagaimana melakukannya. Skenario tindakan yang telah direncanakan, dilaksanakan dalam situasi yang aktual. Pada saat yang bersamaan kegiatan ini juga disertai dengan kegiatan observasi dan interpretasi serta diikuti dengan kegiatan refleksi. Pengamatan interpretasi, meliputi kegiatan perekaman data, yaitu proses dan hasil dari pelaksanaan kegiatan. Tujuannya adalah untuk mengumpulkan bukti hasil tindakan agar dapat dievaluasi dan dijadikan landasan dalam melakukan refleksi. Kegiatan terakhir adalah refleksi, yaitu melakukan analisis data mengenai proses, masalah, dan hambatan yang ditemui dan dilanjutkan dengan refleksi terhadap dampak pelaksanaan tindakan yang dilaksanakan.

Penelitian ini dilaksanakan di SMP Muhammadiyah Kupang tahun ajaran 2018/2019 dengan subjek penelitiannya adalah siswa kelas VII A yang berjumlah 32 siswa. Teknik analisis data yang digunakan ialah teknik analisis deskriptif kualitatif dan kuantitatif. Data kualitatif berupa, lembar pengamatan, wawancara dan dokumentasi. Teknik analisis kuantitatif dilakukan untuk mendeskripsikan data dari hasil kemampuan menulis teks eksposisi siswa dengan menggunakan metode colloborative writing di setiap akhir siklus.

Analisis kuantitatif dalam penelitian ini menggunakan statistik dengan formula sebagai berikut (Daryanto, 2014):

$\bar{X}=\frac{\sum X}{\sum N}$

Keterangan:

$\bar{X}=$ Nilai rata-rata

$\sum X=$ Jumlah semua nilai siswa

$\sum N=$ Jumlah Siswa

Sesuai dengan karakteristik Penelitian Tindakan Kelas, keberhasilan penelitian ini ditandai adanya peningkatan proses dan hasil pembelajaran. Keberhasilan proses diperoleh jika: (1) proses pembelajaran dilaksanakan secara 
menarik dan menyenangkan, (2) siswa berpartisipasi aktif dalam proses pembelajaran, dan (3) siswa mampu memahami pembelajaran dengan menggunakan metode Collaborative Writing. Sedangkan keberhasilan atau peningkatan hasil/produk diperoleh jika terjadi peningkatan nilai menulis mencapai nilai rata-rata 70,00.

\section{Hasil dan Pembahasan}

Kegiatan penelitian yang dilakukan pada pratindakan ini untuk mengetahui kemampuan awal siswa dalam pembelajaran bahasa Indonesia, khususnya menulis teks eksposisi. Seperti sudah dijelaskan di awal bahwa berdasarkan hasil pengamatan pembelajaran di kelas dan wawancara dengan guru bahasa Indonesia kelas VII A SMP Muhammadiyah Kota Kupang tahun ajaran 2018/2019, ada beberapa masalah dalam proses pembelajaran menulis teks eksposisi sebagai berikut: (1) siswa kurang semangat dan bosan dalam proses pembelajaran menulis teks eksposisi, dan (2) banyak siswa yang bermain-main dan bahkan tertidur saat proses pembelajaran berlangsung. Penyebab utama dari persoalan ini adalah (1) strategi pembelajaran yang digunakan dalam proses pembelajaran masih konvensional sehingga kurang membangkitkan semangat siswa dalam mengikuti proses pembelajaran, dan (2) siswa menganggap pembelajaran menulis membosankan.

Pembelajaran dengan menggunakan strategi konvensional belum memberikan hasil yang maksimal terhadap proses pembelajaran menulis teks eksposisi. Selain itu kemampuan menulis teks eksposisi siswa juga perlu ditingkatkan. Peningkatan dimaksud dapat diwujudkan dengan melakukan tindakan siklus I dengan pembelajaran menggunakan metode Collaborative Writing.

\section{Siklus I}

Pelaksanaan tindakan kelas pada siklus I dilakukan selama 3 kali pertemuan, yakni 2 pertemuan pemberian materi dan 1 pertemuan untuk tes. Pada siklus ini peneliti bertindak sebagai guru yang melangsungkan semua kegiatan pembelajaran dan guru mata pelajaran sebagai penilai proses dan hasil pembelajaran. Pelaksanaan tindakan pada siklus I dilaksanakan pada tanggal 19 Februari, 22 Februari dan 26 Februari 2019. Dalam pelaksanaan tindakan peneliti bekerjasama dengan guru bahasa Indonesia sebagai kolaborator. Adapun hasil pelaksanaan tindakan dalam 3 pertemuan pada siklus I dapat dijelaskan secara rinci dalam tabel berikut.

Tabel 1. Hasil Menulis Teks Eksposisi Siswa pada Siklus I 


\begin{tabular}{|c|c|c|c|c|c|c|c|}
\hline \multirow{2}{*}{$\begin{array}{l}\text { Nama } \\
\text { Siswa }\end{array}$} & \multicolumn{5}{|c|}{ Aspek penilaian } & \multirow[b]{2}{*}{ Jumlah } & \multirow{2}{*}{$\begin{array}{l}\text { Skor } \\
\text { Akhir }\end{array}$} \\
\hline & Isi & $\begin{array}{l}\text { Organisas } \\
\text { i struktur }\end{array}$ & $\begin{array}{l}\text { Kosa } \\
\text { kata }\end{array}$ & $\begin{array}{c}\text { Penggunaan } \\
\text { bahasa }\end{array}$ & Mekanik & & \\
\hline Siswa 1 & 2 & 2 & 2 & 2 & 2 & 10 & 50 \\
\hline Siswa 2 & 3 & 3 & 2 & 2 & 2 & 12 & 60 \\
\hline Siswa 3 & 3 & 3 & 3 & 3 & 2 & 14 & 70 \\
\hline Siswa 4 & 2 & 2 & 3 & 2 & 2 & 11 & 55 \\
\hline Siswa 5 & 3 & 3 & 2 & 2 & 2 & 12 & 60 \\
\hline Siswa 6 & 3 & 3 & 3 & 3 & 3 & 15 & 75 \\
\hline Siswa 7 & 2 & 3 & 2 & 2 & 2 & 11 & 55 \\
\hline Siswa 8 & 2 & 2 & 2 & 3 & 2 & 11 & 55 \\
\hline Siswa 9 & 3 & 3 & 3 & 3 & 3 & 15 & 75 \\
\hline Siswa 10 & 3 & 2 & 2 & 3 & 2 & 12 & 60 \\
\hline Siswa 11 & 2 & 3 & 2 & 3 & 2 & 12 & 60 \\
\hline Siswa 12 & 4 & 4 & 3 & 4 & 2 & 17 & 85 \\
\hline Siswa 13 & 2 & 3 & 3 & 3 & 2 & 13 & 65 \\
\hline Siswa 14 & 3 & 3 & 3 & 3 & 3 & 15 & 75 \\
\hline Siswa 15 & 4 & 3 & 3 & 3 & 4 & 17 & 85 \\
\hline Siswa 16 & 2 & 3 & 3 & 2 & 2 & 12 & 60 \\
\hline Siswa 17 & 2 & 3 & 3 & 3 & 2 & 13 & 65 \\
\hline Siswa 18 & 4 & 3 & 3 & 3 & 4 & 17 & 85 \\
\hline Siswa 19 & 3 & 2 & 2 & 3 & 3 & 13 & 65 \\
\hline Siswa 20 & 3 & 2 & 3 & 2 & 2 & 12 & 60 \\
\hline Siswa 21 & 4 & 3 & 3 & 3 & 3 & 16 & 80 \\
\hline Siswa 22 & 3 & 3 & 2 & 3 & 2 & 13 & 65 \\
\hline Siswa 23 & 3 & 3 & 3 & 2 & 2 & 13 & 65 \\
\hline Siswa 24 & 4 & 4 & 3 & 3 & 3 & 17 & 85 \\
\hline Siswa 25 & 4 & 4 & 2 & 3 & 3 & 16 & 80 \\
\hline Siswa 26 & 2 & 3 & 3 & 2 & 3 & 13 & 65 \\
\hline Siswa 27 & 3 & 3 & 2 & 2 & 3 & 13 & 65 \\
\hline Siswa 28 & 4 & 4 & 2 & 2 & 3 & 15 & 75 \\
\hline Siswa 29 & 2 & 3 & 3 & 2 & 3 & 13 & 65 \\
\hline
\end{tabular}




\begin{tabular}{llllllll}
\hline Siswa 30 & 4 & 3 & 3 & 4 & 2 & 16 & 80 \\
\hline Siswa 31 & 2 & 2 & 3 & 2 & 2 & 11 & 55 \\
\hline Siswa 32 & 2 & 2 & 3 & 3 & 3 & 13 & 65 \\
\hline & & Jumlah & & 2115 \\
\hline & Rata-rata & & 66,09 \\
\hline
\end{tabular}

Berdasarkan Tabel 1 dapat diketahui bahwa nilai rata-rata siswa pada siklus I yaitu 66,09 sehingga belum mencapai Kriteria Kelulusan Minimum (KKM). Hal ini juga dibuktikan dengan hasil pengamatan proses kegiatan pembelajaran pada tabel berikut ini;

Tabel 2. Hasil Pengamatan Siswa Selama Proses Pembelajaran Siklus I

\begin{tabular}{|c|c|c|c|}
\hline \multirow{2}{*}{ No } & \multirow{2}{*}{ Aspek } & \multicolumn{2}{|c|}{ Keterangan } \\
\hline & & Pertemuan I & Pertemuan II \\
\hline 1 & $\begin{array}{l}\text { Siswa menunjukkan minat/antusias terhadap } \\
\text { materi pembelajaran }\end{array}$ & C & B \\
\hline 2 & $\begin{array}{l}\text { Keberanian siswa bertanya dan menjawab } \\
\text { pertanyaan selama proses pembelajaran }\end{array}$ & K & C \\
\hline 3 & Keaktifan siswa membaca teks eksposisi & C & B \\
\hline 4 & Keaktifan siswa dalam menulis & C & B \\
\hline 5 & $\begin{array}{l}\text { Keberanian siswa membacakan hasil karyanya } \\
\text { di depan kelas }\end{array}$ & C & B \\
\hline
\end{tabular}

Berdasarkan Tabel 2 dapat dilihat bahwa pada pertemuan pertama pada aspek keaktifan siswa mendapatkan kategori cukup dan mengalami peningkatan pada pertemuan kedua mendapatkan kategori baik. Selanjutnya dilihat dari aspek keberanian siswa untuk bertanya dan menjawab pertanyaan pada pertemuan pertama mendapat kategori kurang dan kedua siswa mendapat kategori cukup, karena siswa masih terlihat malu-malu untuk bertanya dan menjawab pertanyaan. Dilihat dari aspek keaktifan membaca dan menulis pada pertemuan pertama siswa mendapatkan kategori cukup karena sebagian siswa masih bersenda gurau bersama teman kelompoknya, namun pada pertemuan kedua siswa mulai aktif. Begitupun pada aspek keberanian membacakan hasil tulisan di depan kelas pada siklus I pertemuan pertama mendapatkan kategori cukup dan mendapat kategori baik pada 
pertemuan kedua karena pada pertemuan pertama tidak ada inisiatif dari siswa untuk membacakan hasil karyanya di depan kelas.

Setelah melakukan tindakan dan pengamatan, peneliti melakukan refleksi terhadap penelitian yang telah dilakukan di siklus I. Temuan penelitian menunjukkan: (1) siswa masih banyak yang melakukan penyingkatan kata, masih banyak kesalahan huruf kapital, dan titik serta tanda koma belum jelas, (2) masih ada siswa yang belum aktif dalam proses pembelajaran,(3) siswa kurang memahami struktur teks eksposisi, dan (4) siswa masih kesulitan mengolah dan mengembangkan topik menjadi sebuah teks yang utuh.

Berdasarkan hasil pembelajaran menulis teks eksposisi pada siklus I, nilai rata-rata yang diperoleh pada siklus I sebesar 66,09 yang berarti belum mencapai KKM yakni 70,00. Oleh karena itu, perlu dilakukan tindakan siklus II.

\section{Siklus II}

Pelaksanaan pada siklus II pada dasarnya tidak jauh berbeda dengan tindakan siklus I. Pada tindakan siklus II, peneliti berkonsultasi kembali dengan guru bahasa Indonesia untuk mengevaluasi kembali pembelajaran yang sudah dilakukan pada 3 pertemuan sebelumnya. Peneliti diberi masukan oleh guru bahasa Indonesia untuk lebih mengeksplorasi strategi Collaborative Writing yang sudah diterapkan sebelumnya. Peneliti diberi masukan agar melakukan pendekatan secara personal kepada siswa yang masih kurang mampu dalam menulis teks eksposisi. Selain itu peneliti dan guru mata pelajaran memilih model teks yang lebih mudah dipahami oleh siswa, membiarkan siswa memilih topik yang ingin mereka kembangkan dalam sebuah teks eksposisi agar siswa lebih bebas berekspresi menuangkan apa yang ada dalam pikirannya.

Pelaksanaan penelitian tindakan pada siklus II dilakukan selama tiga kali pertemuan, yakni pada tanggal 01 Maret, 05 Maret, dan 08 Maret 2019. Dua pertemuan awal bersifat mengulangi materi pada siklus 1 dan satu pertemuan terakhir melakukan evaluasi. Hasil evaluasi tindakan pada siklus II dijelaskan dalam tabel berikut. 
Peningkatan Kemampuan Menulis...

Tabel 3. Hasil Menulis Teks Eksposisi Siswa pada Siklus II

\begin{tabular}{|c|c|c|c|c|c|c|c|}
\hline \multirow{2}{*}{$\begin{array}{l}\text { Nama } \\
\text { Siswa }\end{array}$} & \multicolumn{5}{|c|}{ Aspek penilaian } & \multirow[b]{2}{*}{ Jumlah } & \multirow{2}{*}{$\begin{array}{l}\text { Skor } \\
\text { Akhir }\end{array}$} \\
\hline & Isi & $\begin{array}{l}\text { Organisas } \\
\text { i struktur }\end{array}$ & $\begin{array}{l}\text { Kosa } \\
\text { kata }\end{array}$ & $\begin{array}{c}\text { Penggunaan } \\
\text { bahasa }\end{array}$ & Mekanik & & \\
\hline Siswa 1 & 3 & 3 & 3 & 2 & 2 & 13 & 65 \\
\hline Siswa 2 & 3 & 3 & 3 & 3 & 3 & 15 & 75 \\
\hline Siswa 3 & 4 & 4 & 3 & 3 & 4 & 18 & 90 \\
\hline Siswa 4 & 3 & 3 & 3 & 3 & 2 & 14 & 70 \\
\hline Siswa 5 & 3 & 3 & 2 & 3 & 2 & 13 & 65 \\
\hline Siswa 6 & 3 & 3 & 3 & 3 & 4 & 16 & 80 \\
\hline Siswa 7 & 3 & 3 & 2 & 2 & 2 & 12 & 60 \\
\hline Siswa 8 & 3 & 3 & 3 & 2 & 2 & 13 & 65 \\
\hline Siswa 9 & 4 & 4 & 3 & 3 & 3 & 17 & 85 \\
\hline Siswa 10 & 3 & 2 & 2 & 3 & 2 & 12 & 60 \\
\hline Siswa 11 & 3 & 3 & 3 & 3 & 3 & 15 & 75 \\
\hline Siswa 12 & 4 & 4 & 3 & 3 & 3 & 17 & 85 \\
\hline Siswa 13 & 3 & 3 & 3 & 3 & 3 & 15 & 75 \\
\hline Siswa 14 & 4 & 3 & 3 & 3 & 3 & 16 & 80 \\
\hline Siswa 15 & 4 & 3 & 3 & 3 & 4 & 17 & 85 \\
\hline Siswa 16 & 3 & 3 & 3 & 2 & 2 & 13 & 65 \\
\hline Siswa 17 & 3 & 3 & 3 & 2 & 2 & 13 & 65 \\
\hline Siswa 18 & 4 & 3 & 3 & 3 & 4 & 17 & 75 \\
\hline Siswa 19 & 3 & 3 & 3 & 2 & 2 & 13 & 65 \\
\hline Siswa 20 & 3 & 3 & 3 & 3 & 2 & 14 & 70 \\
\hline Siswa 21 & 4 & 3 & 3 & 3 & 3 & 16 & 80 \\
\hline Siswa 22 & 3 & 3 & 2 & 3 & 2 & 13 & 65 \\
\hline Siswa 23 & 3 & 3 & 3 & 3 & 3 & 15 & 75 \\
\hline Siswa 24 & 4 & 4 & 3 & 3 & 3 & 17 & 85 \\
\hline Siswa 25 & 4 & 4 & 2 & 3 & 3 & 16 & 80 \\
\hline Siswa 26 & 3 & 3 & 3 & 3 & 3 & 15 & 75 \\
\hline Siswa 27 & 4 & 3 & 3 & 3 & 3 & 16 & 80 \\
\hline Siswa 28 & 4 & 4 & 2 & 2 & 3 & 15 & 75 \\
\hline
\end{tabular}




\begin{tabular}{llllllll}
\hline Siswa 29 & 3 & 3 & 3 & 3 & 3 & 15 & 75 \\
\hline Siswa 30 & 4 & 3 & 3 & 4 & 4 & 18 & 90 \\
\hline Siswa 31 & 3 & 3 & 2 & 2 & 3 & 13 & 65 \\
\hline Siswa 32 & 3 & 3 & 3 & 3 & 3 & 15 & 75 \\
\hline & & Jumlah & & & 2.385 \\
& & Rata-rata & & \\
\hline
\end{tabular}

Berdasarkan tabel di atas nilai rata-rata siswa pada siklus II yaitu 74, 53. Nilai pada siklus II jika dibandingkan pada siklus I terjadi peningkatan dan telah mencapai Kriteria Kelulusan Minimal. Hal ini didukung oleh hasil pengamatan proses pembelajaran di bawah ini.

Tabel 4. Hasil Pengamatan Kegiatan Siswa Selama Proses Pembelajaran

\begin{tabular}{lllc}
\hline \multirow{2}{*}{ No } & & \multicolumn{2}{c}{ Keterangan } \\
\cline { 3 - 4 } & & Siswa menunjukkan minat/antusias terhadap & Pertemuan II \\
\hline 1 & materi pembelajaran & S & B \\
\hline 2 & Keberanian siswa bertanya dan menjawab & B & B \\
\hline 3 & Keaktifan siswa membaca teks eksposisi & B \\
\hline 4 & Keaktifan siswa menulis teks eksposisi & B & SB \\
\hline 5 & Keberanian siswa membacakan hasil tulisannya di & B & \\
\hline
\end{tabular}

Berdasarkan hasil pengamatan pada tabel di atas, dapat diketahui bahwa adanya peningkatan kinerja pembelajaran teks eksposisi menggunakan strategi Collaborative Writing. Aspek yang pertama yaitu pada aspek minat belajar siswa, antusias siswa dalam mengikuti pembelajaran, peningkatan yang kedua yaitu pada aspek keberanian bertanya dan menjawab, siswa mulai mengangkat tangan untuk bertanya dan menjawab pertanyaan yang diberikan. Pada aspek keaktifan siswa dalam membaca dan menulis pada siklus II, menunjukkan adanya sikap positif. Kegiatan belajar menulis teks eksposisi menggunakan strategi Collaborative Writing disambut baik oleh siswa. Berbeda dengan kegiatan pada siklus I, pembelajaran 
menulis teks eksposisi pada siklus II lebih menyenangkan. Siswa lebih antusias dan bersemangat. Hal itu dapat dilihat dari aktivitas siswa selama proses pembelajaran menulis teks eksposisi berlangsung. Siswa lebih aktif dalam bertanya dan menjawab pertanyaan.

Refleksi pada siklus II dilakukan oleh peneliti dan guru sebagai berikut. Penggunaan metode Collaborative Writing yang digunakan berjalan dengan baik, sebagian besar siswa aktif dalam mengikuti pembelajaran, hampir seluruh siswa mengikuti pembelajaran dengan senang dan tenang serta terdapat peningkatan nilai dan sikap sesuai yang di harapkan. Hasil tindakan siklus II terlihat adanya peningkatan yaitu nilai rata-rata pada kegiatan siklus II sebesar 74,53. Nilai tersebut telah meningkat jika dibandingkan dengan nilai rata-rata pada siklus I.

Berdasararkan hasil temuan tersebut di atas, diketahui bahwa metode Collaborative Writing dapat mendorong siswa untuk saling belajar serta salling memotivasi siswa untuk menulis, mempelajari cara siswa lain menulis, serta mempelajari referensi lebih banyak.

\section{Simpulan}

Berdasarkan hasil penelitian tindakan kelas ini, dapat disimpulkan bahwa metode Collaborative Writing dapat meningkatkan kemampuan siswa dalam pembelajaran menulis teks eksposisi siswa kelas VII A SMP Muhammadiyah Kupang tahun ajaran 2018/2019. Penggunaan metode Collaborative Writing yang digunakan berjalan dengan baik yang dapat dibuktikan pada keaktifan sebagian besar siswa dalam mengikuti pembelajaran. Dalam hal ini, hampir seluruh siswa mengikuti pembelajaran dengan senang dan tenang serta terdapat peningkatan nilai dan sikap sesuai yang diharapkan. Melalui metode Collaborative Writing masing-masing siswa tidak hanya bertanggung jawab untuk mempelajari apa yang diajarkan tetapi juga bertanggung jawab membantu temannya untuk belajar dan memahami pelajaran yang mereka dapatkan. 


\section{Referensi}

Alwasilah, A. C. (2004). The Tapestry of English Language Teaching and Learning in Indonesia. Malang: State University of Malang Press.

Aqib, Z. (2006). Penelitian Tindakan Kelas untuk Guru. Bandung: Yrama Widya.

Azmussya'ni, Wangid, \& Nur, M. (2014). Peningkatan Keterampilan Menulis Menggunakan Pendekatan Proses Dengan Media Gambar di SDN 3 Sakra. Jurnal Prima Edukasi, 2(1).

Cameron, L. (2001). Teaching Languages to Young Learners. Cambridge: Cambridge University Press.

Daeng Pawero, A. M. V. (2018). Analisis Kritis Kebijakan Kurikulum Antara KBK, KTSP, dan K-13. Jurnal Ilmiah Iqra', 12(1), 42. https://doi.org/10.30984/jii.v12i1.889

Dalman. (2016). Keterampilan Menulis. Jakarta: Raja Grafindo Persada.

Daryanto. (2014). Penelitian Tindakan Kelas dan Penelitian Tindakan Sekolah. Yogyakarta: GAVA MEDIA.

Gie, T. L. (2002). Terampil Mengarang. Yogyakarta: Andi Offset.

Jamhar, R., \& Dkk. (2018). Peningkatan Kemampuan Menulis Teks Prosedur dengan Menggunakan Media Gambar Seri pada Siswa kelas XI IPS SMA Muhammadiyah Kupang Tahun Ajaran 2018/2019. In Prosiding Seminar Nasional Hibah Program Penugasan Dosen ke Sekolah (PDS). Padang: Universitas Negeri Padang.

Luna, A. M. R., \& Ortiz, L. S. H. (2013). How A Colombian Journal for Teachers of English. Collaborative Writing to Enhance Academic Writing Development Through Project Work, 130-148.

Pawero, A. M. (2017). Analisis Kritis Kebijakan Standar Kompetensi Lulusan (SKL) Dan Standar Isi Kurikulum Pendidikan Agama Islam. Journal of Islamic Education Policy, 2(2). https://doi.org/10.30984/j.v2i2.700

Richards, J. C., \& Renandya, W. A. (2002). Methodology in Language Teaching: An Anthology of Current Pranctise. Cambridge: Cambridge University Press.

Shachar, H. (2003). Who Gains what from Cooperative Learning: An overview of eight studies. London: Routledge.

Widodo, H. P. (2006). Teaching Cooperative Writing. Guidelines, 28(1), 27-33. 